\title{
Effectiveness Of Implementation Of Corporate Social Responsibility (CSR) In The Environmental Law Enforcement
}

\author{
Irwansyah $^{1}$, Gianto $^{2}$ and Andi Syahwia ${ }^{3}$ \\ ${ }^{1}$ Faculty of Law, Hasanuddin University \\ Jln. Perintis Kemerdekaan Km.10, Tamalanrea, Makassar, 90245, Indonesia \\ Tel./Fax: +62-411-587219 E-mail: irwansyahrawydharma@yahoo.com \\ ${ }^{2}$ Faculty of Law, Hasanuddin University \\ Jln. Perintis Kemerdekaan Km.10, Tamalanrea, Makassar, 90245, Indonesia \\ Tel./Fax:+62-411-587219 E-mail: Giantoanto81@yahoo.com \\ ${ }^{3}$ Faculty of Law, Hasanuddin University \\ Jln. Perintis Kemerdekaan Km.10, Tamalanrea, Makassar, 90245, Indonesia \\ Tel./Fax:+62-411-587219 E-mail : Giantoanto81@yahoo.com
}

\begin{abstract}
Development in Indonesia refers to the concept of sustainable development (sustainable development) and responsibility for the environment. Companies have a social responsibility to social and environmental consequences of environmental damage that caused. Implementation of corporate social responsibility ( Cooperate Social Responsibility) is an important part in the framework part of the enforcement of environmental law. Implementation of CSR growing rapidly, including in Indonesia . Through Law No. 40 Year 2007 regarding Limited Liability Company, specifically in Article 74, in response to the action of the business world to social and environmental causes damages to society. But in application / CSR implementation will be undertaken by the company is not maximized with implications for the enforcement of environmental law.
\end{abstract}

Keywords: Effectiveness; Corporate Social Responsibility (CSR); Environmental Law Enforcement

\section{INTRODUCTION}

Environment around us is the grace of Allah that for humans. In other religion's teachings clearly Allah wants his creation to empower people and preserve the environment as well as possible. However, the fact that Allah desires that can not be achieved by mankind, in many places frequent destruction and pollution of the environment, including in the area of environment we live in Indonesia.

Development in Indonesia refers to the concept of sustainable development and responsibility for the environment. Indonesia as one investment destination in dire need of their protection to the interests and the country's investment environment. 
In order to protect the environment and the ecosystem in general from A efforts, and all stakeholders are obliged to conduct environmental protection and management in the implementation of sustainable development so that the Indonesian environment and can remain a source of life support for the Indonesian people and other living creatures.

Environment is an important thing in human life cycle. In Law No. 32 of 2009 on the Protection and Environmental Management at the Article 1 (1) which reads "The environment is a unity with all things space, power, state, and living creatures, including humans and their behavior, which affect the nature itself, the continuity of livelihoods, and the wellbeing of humans and other living creatures $"$.

Indonesia's environmental law has developed rapidly over the last four decades. Most of these developments is a response to the influence of international environmental law, which is closely linked to the influence of the development of science and economic costs. On the other hand, environmental law, whether national or local, often located in front of the public as a modification of social. ${ }^{1}$

\footnotetext{
1 Mas Achmad Santosa dan Margaretha Quena. (2014). Gerakan Pembaruan Hukum Lingkungan Indonesia dan Perwujudan Tata Kelola Lingkungan Yang
}

Countries Indonesia has a wealth of natural resources are abundant. The abundance of natural resources owned is certainly the main attraction for other countries and even the company - a company engaged in exploration in order to reap the benefits of the exploration of natural resources. The exploration activities are carried out would result in an impact on the survival of the environment and even the survival of the population/ community around the company area.

Companies no longer just economic activities to create profits for the sake of its survival, but also responsible for the social and environmental aspects. The rationale is dependent solely on the financial health of the company can not ensure sustainable growth (sustainable). Sustainability will be guaranteed if companies pay attention to other related aspects, the social and environmental aspects. ${ }^{2}$

Destruction and pollution of the environment are often linked to the lack of public access to information, both about the changes in the environmental conditions it faces, such as pollutants that affect health, as well as at the level of

\footnotetext{
Baik dalam Negara Demokrasi, Jurnal Hukum Lingkungan Indonesia.Indonesian Center for Environmental Law (ICEL), 01 (01): 90

${ }^{2}$ Bambang Rudito \& Arif Budimanta \& Adi Prasetijo. (2004). Corporate Social Responsibility: Jawaban Bagi Modal Pembangunan Indonesia Masa Kini. Jakarta: ICSD, pg.34
} 
decision-making that affects the community, both general and technical as the business licensing / activity ${ }^{3}$ that harm the community around the company. Actually, the problem cannot be separated from the paradigm ${ }^{4}$ the business world, particularly in the environmental industry that still puts profits (profit-oriented), not to mention lead to the image of the company (corporate image). This meant that the company is no longer as an entity that is selfish (selfish), alienation and or exclusivity of the community, but rather a business entity that is required to conduct cultural adaptation to the social environment in which it is located and is responsible for any damage and the impact environment as a result of business activity they are doing. And on the other hand, companies need to recognize that a company cannot live, operate and survive

\footnotetext{
3 Prayekti Murharjanti. (2008). Menutup Akses Menuai Bencana (Potret Pemenuhan Akses Informasi, Partisipasi, dan Keadilan dalam Pengelolaaan Lingkungan Hidup dan Sumber Daya Alam di Indonesia. Mold. I. Jakarta: ICEL. pg. 27.

${ }^{4}$ Paradigm is a term coined by Thomas S. Kuhn in an attempt to find answers to a change to a new state that is seen as a revolutionary process. While the paradigm is aimed at two main sense; first; as the totality of the constellation of ideas, beliefs, values, perceptions and techniques embraced by academics and practitioners of particular disciplines that affect the reality of their worldview. Second; in an effort to unravel the science of man is capable of overturning all the assumptions and rules. More see in Lili Rasjidi dan I.B. Wyasa Putra. (1993). Hukum sebagai Suatu Sistem, Remaja Rosdakarya, Bandung, pg. 66-70, dan Sofian Effendi. (1988). Paradigma Pembangunan dan Administrasi Pembangunan, in LAN RI, Meeting Reports Assess and the Role of Science in Development Administration and Management, Jakarta, pg. 188.
}

and make a profit without the help of various parties.

Development is done massively in Indonesia can increase prosperity, but on the other hand can also have negative impacts on the environment.

The impact resulting from environmental pollution allegedly from an industrial effluent process resulted in the destruction of ecosystems (contamination of fish and water), air pollution due to the operation of companies - large companies that would use high technology, as well as resulting in a number of diseases in the surrounding communities.

Companies actually have to have a positive response to the impact on environmental damage. The positive response may include the provision of assistance (scholarships), reforestation of the forest damage, even in the context of multinational companies in the running and so forth. The good intentions of the owners of the company can be realized if the state authority power holders have a stake in it. Government intervention in this case is to conduct adequate environmental protection laws. Protection and law enforcement in the field of environment is very important because the environment is an important asset of the country. 
From the background as described above in the issues raised in this paper is how is the effectiveness of the implementation of Corporate Social Responsibility (CSR) in the enforcement of environmental law.

\section{ANALYSIS AND DISSCUSSION The meaning or definition of Corporate Social Responsibility (CSR)}

Many definitions explain the meaning of CSR. However, the meaning of CSR is constantly changing over time when a family or a business owner running a business, CSR programs associated with charity - donations or philanthropy corporate philanthropy.

Until now there has been a unity of language on CSR, it can be seen from different understanding or definition of CSR as follows: 5

a. The World Business Council for Sustainable Development (WBCSD) ${ }^{6}$ WBCSD formulate CSR as : "The continuing commitment by business to behave ethically and contribute to

\footnotetext{
${ }^{5}$ Isa Wahyudi \& Busyra Azheri. (2008). Corporate Social Responsibility, Prinsip, Pengaturan dan Implementasi, Malang: Intrans Publishing dan Inspire. pg. 28.

${ }^{6}$ www.wbcsd.org. Corporate Social Responsibility. (2001). Making Framework for Corporate Social Responsibility, Washington. WBCSD is an international organization as an association of companies comprised of \pm 180 transnational companies from \pm 35 countries which are committed to the "Making Good Business Sense", accessed May 31, 2016.
}

economic development while improving thequality of life of the workforce and their families as well as of the local community and society at large to improve their quality of life".

b. World Bank

This global financial institutions formulate CSR as "the commitment of business to contribute to sustainable economic development working with employees and their representatives, the local community and society at large to improve quality of life, in ways that are both good for business and good for development".

c. European Union

Europen Union or Uni Eropa as an association of institutions of countries in the European continent to formulate the notion of CSR in EU Green Papaer on CSR as “....... is a concept whereby companies integrate social and environmental concerns in their business operations and in their interaction with their stakeholderss on a voluntary basic". More The Europen Commission also reiterated that CSR is "Being socially responsibility means not only fulfilling legal expectations, but 
also going beyond compliance and investing more into human capital, the enviroment and relations with stakholders".

d. CSR Forum also provides formulate the notion of CSR is "CSR mean open and transparent business practices that are based on ethical values and respect for employeses, communities and enviroment".

The same condition also occurs in the context of the provisions of the legislation, such as:

a. Elucidation of Article $15 \mathrm{~b}$ of Law Number 25 Year 2007 regarding Investment (abbreviated Capital Market Law) which states that "corporate social responsibility is a responsibility that is inherent in each investment company to create harmonious relations, balanced, and in accordance with the environment, values, norms, and culture of the local community ".

b. Article 1 paragraph 3 of Law Number 40 Year 2007 on the Company Limited (abbreviated as the Company Law) also asserts that "the social responsibility and the environment is the company's commitment to participate in the sustainable economic development to improve the quality of life and environment benefits the company itself, the local community and society in general ".

The above understanding can be interpreted to mean that any individual or legal entity (company) have committed in their business activities to contribute to building a sustainable economy with the aim of improving the quality of life, to not only to its employees or represented of the family as well as to the local community and even global, in commitment the integrated economic development program or activity CSR. ${ }^{7}$

According to B Taman Achda, the concept of CSR (Corporate Social Responsibility program of) in Indonesia, the which relevant is in the form of empowerment and community development or Often called Community Development. According to the program recommended for the $\mathrm{CD}$ is dedicated to; increasing income (economy) or the public welfare, employment problems, improvement of education, public health, strengthening local institutions and availability of adequate basic infrastructure. $^{8}$

\footnotetext{
7 Abdul Rasyid Idris. (2009). Corporate Social Responsibility sebagai Sebuah Gagasan. Jakarta: Fokus Sahabat, pg. 45

${ }^{8}$ Hendrik Budi Untung. (2009). Corporate Social Responsibility, Jakarta: Sinar Grafika, pg. 16
} 
Meanwhile, according to the formulation of Trinidad and Tobacco Bureau of Standards (TTBS) concluded that CSR is associated with values and standards are made with regard to the operation of a company. CSR thus be interpreted as a commitment in trying ethically, operating legally and contribute to economic improvement, along with improved quality of life of employees and their families, local communities and society at large. Then John Elkingston's affirmed as follows: ${ }^{9}$

"Corporate Social Responsibility is a concept that organisation, especially (but not only) corporations, have an obligation to consider the interests of costomers, employees, shareholders, communities, and ecological considerations in all aspects af their operations. This obligation is been to extend beyond their statutory obligation to comply with legislation".

The formulation of CSR is more emphasis on the concept of a company to ignore its obligations to customers, employees, shareholders, communities, and ecological in all aspects of its activities. Later he also confirmed that the obligation in question is much broader than the obligation by law to comply with the laws and regulations that exist.

\footnotetext{
${ }^{9}$ John Elkington in Teguh Sri Pembudi. (2005). CSR Suatu Keharusan, dalam Investasi Sosial, Jakarta: Puspinsos, pg. 19.
}

Similarly, Michael Hopkins in its Working Paper conveyed to the Policy Integration Department of the World Commission on the Social Dimension of Globalization International Labour Office, Geneva 2004 explained that CSR is : ${ }^{10}$

"CSR is concerned with treating the stakeholders of the firm ethically or in a responsible manner. 'Ethically or responsible' means treating stakeholders in a manner deemed acceptable in civilized societies. Social includes economic responsibility, stakeholders exist both within a firm and outside. The natural environment is a stakeholder. The wider aim of social responsibility is to create higher and higher standards of living, while preserving the profitability of the corporation, for people both within and outside the corporation".

From the description of Michael Hopkins shows that CSR relates to the treatment of companies towards stakeholders both inside and outside the company including ethically or environmentally responsible manner, by treating the stakeholders in a way that can be received. While CSR covers social responsibility in the economic field in order to create better living standards while maintaining profitability.

\footnotetext{
${ }^{10}$ Michael Hopkins. (2003). The Business Case for CSR : Where are we? International Journal for Business Performent Management, 5 (23): 125.
} 
Definition and concept of CSR had been developed, expert accounting Davis and Frederick in 1992 stated that CSR is an obligation organizations or companies to take part in activities aimed at protecting and improving the welfare of society as a whole in addition to the activities aimed at the interests of the organization own. ${ }^{11}$

Then Farmer and Hogue stated that "Social responsibility action by a corporation are action that, when judged by society in the future, are seen to have been maximum help in providing necessary amounts of desired goods and service at minimum financial and social cost, distributed as equatably as posible ${ }^{12}$. In this case Farmer and Hogue emphasized that the company's commitment to CSR is able to deliver what people want.

Thus, CSR is a concern for companies to set aside some of its profits (profit) for the benefit of human development (people) and the environment (planet) in a sustainable manner based on the procedure (procedure) is appropriate and professional.

Of the various terms or definitions of the above it can be concluded that CSR is a company's commitment to meeting the

${ }^{11}$ R. Dwi. (1998). Peranan Akuntansi Sosial dalam Menilai Tanggung Jawab Sosial, Thesis, not published, research on Pabrik Gula Kebonagung, Malang.

${ }^{12}$ Richard N.Farmer \& Dickerson W. Hogue. (1988). Corporate Social Responsibility. Toronto: DC Healt and Company, pg. 87. obligations based on the decision to adopt policies and measures with regard to the interests of stakeholders and the environment in which the company conducts its activities based on the applicable law.

According to the Prince of Wales International Business Forum, there are five (5) pillars of CSR activities is as follows : ${ }^{13}$

a. Building human capital is related to the company's internal human resources to create a reliable, while externally the company is required to empower the community.

b. Strengthening economies is the company required to not become rich himself while poor communities in their environment. Companies should empower the surrounding economy.

c. Assessing social chesion is an attempt to maintain harmony with the surrounding communities in order to avoid conflict.

d. Encouraging good governance is a company in running the business, should refer to the Good Corporate Governance (GCG).

e. Protecting the environment is a company must strive to preserve the environment.

\footnotetext{
${ }^{13}$ http://www: ibl.or.id, Accessed 8 Mei 2016.
} 
Of the five pillars iru showed that CSR is much broader in scope than community development. The most fundamental difference visible on the scope of CSR that includes 3BL sustainable and lasting basis. Monitoring and evaluation of programs is needed in order to target the right activities, even report (reporting) as a reflection of output used as feedback. ${ }^{14}$

Now, along with the complexity of the ownership of a business, CSR concept became widespread meanings, one of which is the "good intentions and commitment of the company to contribute to improving quality of life, sustainable community development, local economy give contributing also to the sustainability of the company and the environment.

In its application 4P concept of the profit or profit, planet concept clearly related to aspects of the environment. The concept of people in it can refer to the concept of social development and human rights are not only about the economic welfare of society (such as the provision of venture capital, job skills training). But

\footnotetext{
14 Because there is no standardization of reporting and still voluntary, so many terms of reporting on CSR activities. No environmental report, citizenship reports, sustainability reports, social reports, environmental and social reports, corporate responsibility reports or corporate social responsibility report. That pretty much so referrals are initiated by the UN Global Compact and the Global Reporting Initiative (GAL), which was launched in 1997 .
}

also, social welfare (such as social security provision, strengthening community access to health services and education, strengthening the capacity of social institutions and local knowledge). While the procedure of the concept could include the concept of organizational governance, labor practices, fair operating practices and consumer issues.

$$
\text { CSR (Corporate Social }
$$
responsibility) is one of the obligations that must be implemented by the company in accordance with the contents of article 74 of Law Company Limited (Company Law) are new. In Article 74, paragraph 1 regulates the obligations of social and environmental responsibility for the company in charge of or relating to Natural Resources, paragraph 2 regarding the calculation of costs and merit and fairness, paragraph 3, regarding the sanctions, and paragraph 4 of the advanced rules.

If drawn on the various terms above, the Corporate Social Responsibility (CSR) is the company's commitment to the interests of the stakeholders in a broader sense than just a mere corporate interests. In other words, although it is morally good that companies and investors chasing profit, not companies or investors justified achieve profits at the expense of the interests of other related parties including 
the impact caused by environmental damage.

\section{Principles that Should be Held in Implementing CSR}

The development of CSR in the Indonesian context (particularly with regard to the implementation of CSR in the category of discretionary responsibilities) can be viewed from two different perspectives. First, the implementation of CSR is a voluntary business practices (discretionary business practices) means that the implementation of CSR initiatives comes from more of the company and is not a required activity for the company by the legislation in force in Indonesia. Second, the implementation of CSR is no longer a discretionary business practice but implementation is governed by law (mandatory).

In a further development of companies - companies operating in Indonesia must hold at least the principles principles applicable law especially environmental law and the principle of social responsibility. to the people affected due to the operation of the company, among the principles are: The first principle is the continuity or sustainability. This does not mean the company will continue to provide assistance to the community.

However, a program designed must have a sustained impact. CSR is different from the donation of natural disasters are unpredictable and can not be predicted. It became generosity and good activity. The second principle, CSR is a long-term program. Companies must realize that a business can grow because of the support of the social atmosphere of the surrounding environment.

Therefore, CSR is a form of maintaining good relations with the community. He is not the moment to boost the popularity of the activity or the pursuit of profit. The third principle, CSR will have a positive impact to the community, both economically, environmentally, and socially. Companies that perform CSR must be caring and considerate of the impact. The fourth principle, the funds are taken for CSR is not incorporated into the cost structure of the company as the budget for marketing that will eventually be transformed into product prices.

\section{Positive and Negative Impact of CSR for the Community}

Positive Impact on Society Neighborhood CSR, among others: the social environment becomes better, the unemployment rate decreased in the midst 
of massive layoffs. While the negative impact of Without the existence of CSR are: The impact of environmental pollution arising from industrial waste in the absence of CSR can be divided into three types:

\section{Impact of Water Pollution}

Contaminated water can have adverse effects on humans are also present in water ecosystems. Losses caused by water pollution can be:

a. Water cannot be used again for domestic purposes, this is caused by water is polluted so it cannot be used anymore let alone have many benefits such as water for drinking, bathing, cooking and washing, etc.,

b. Water cannot be used for industrial purposes, water samples were exposed to oil cannot be used again as a solvent or as water in industrial chemical processes,

c. Water cannot be used for agricultural purposes, such as for irrigation, irrigation and fishing pond. If the water is polluted by an organic compound can lead to drastic changes in water $\mathrm{pH}$. Water that is too acidic or base will kill plants and aquatic animals, other than that water contaminated by sewage B3 causes a lot of dead fish and in humans arises skin diseases (itching).

\section{Impact of Air Pollution}

With the construction of the plant in the smoke can lead to urban air pollution, thus disturbing the comfort for road users. When the air is polluted it will cause diseases such as shortness of breath.

\section{Impact of Soil Pollution}

Land that has been contaminated by pollutants such as carbonate compounds, the land will become acidic, $\mathrm{CO} \mathrm{H} 2 \mathrm{~S}$ which together form toxic compounds in the soil so that the soil bulking worms die. The third impact of this soil contamination can adversely impact the environment mainly as a result of industrial activities PT Unilever when sewage directly discharged without treatment processes first.

\section{Effectiveness Implementation of CSR} (Corporate Social Responsibility) in Environmental Law Enforcement

Corporate Social Responsibility (CSR) is an approach whereby companies integrate social concerns in their business operations and in their interaction with stakeholders based on the principles of partnership and volunteerism.

The term was first pushed CSR into writing Social Responsibility of the Businessman in 1953. The concept was initiated by Howard Rothmann this 
Browen answered concerns the business world. Later CSR immediately adopted, because it could be the antidote the bad impression the company is already in the public mind and over the cap as a businessman in the money hunters who do not care about the impact of poverty and environmental degradation. Although simple, the term CSR is very marketable through CSR employers do not need to be bothered with guilt. CSR is the responsibility of social activities that are not profit-oriented.

\section{The Success Indicators of CSR}

Indicators of success can be seen from two sides of the company and the community. From the corporate side, the image should be getting better in the public eye. Meanwhile, in terms of society, there should be an Increase in quality of life. Therefore, it is important for companies to Evaluate to measure the success of CSR programs, both quantitatively and qualitatively. One thing to remember, "One important measure of success CSR is if the people who helped be independent, not dependent on the help of others.

However, there are still many companies in the field of environment that has not been carrying out its obligations, lack of effectiveness in the implementation of CSR Also result Because The company experienced problems in its application. The problem is in addition to its application not fully comply with Reviews those rules, programs of community development or community development (CD), has not touched the fundamental problems faced by the community. The program Generally has not empower people so that they are prepared for postmining masses. The company in this case has not been Able to Realize the community development program very well Because The estuary of the community development program is community empowerment.

\section{CONCLUSION}

Corporate social responsibility will be successful if there is cooperation between the company and community. To achieve a more equitable world, poverty and sustainable without environmental damage. It takes a paradigm shift, from the fulfillment of "the interests of individuals" into "common interests", ie the change of management "usual corporate responsibility" to "corporate social responsibility".

Effective implementation of CSR in environmental law enforcement in Indonesia is still not optimal. Optimization of the application of CSR is indispensable 
in order to provide protection to the affected people due to environmental degradation.

\section{BIBLIOGRAFY}

Abdul Rasyid Idris. (2009). Corporate Social Responsibility sebagai Sebuah Gagasan. Jakarta: Fokus Sahabat.

Bambang Rudito \& Arif Budimanta \& Adi Prasetijo. (2004). Corporate Social Responsibility: Jawaban Bagi Modal Pembangunan Indonesia Masa Kini. Jakarta: ICSD.

Dirjosisworo Soejono. (1999). Hukum Perusahaan Mengenai Penanaman Modal, Indonesia. Bandung: Mandar Maju.

Dwi Nurwoko. (2006). Sosiologi Teks Pergaulan dan Terapan. Jakarta: Kencana.

Hendrik Budi Untung. (2009). Corporate Social Responsibility. Jakarta: Sinar Grafika.

Husin Sukanda. (2009). Penegakan Hukum Lingkungan Indonesia. Jakarta: Sinar Grafika.

Isa Wahyudi \& Busyra Azheri. (2008). Corporate Social Responsibility, Prinsip, Pengaturan dan Implementasi, Malang: Intrans Publishing dan Inspire.

Jackie Ambadar. (2008). CSR dalam Praktik di Indonesia. Jakarta: Elex Media Komputindo.

Mas Achmad Santosa dan Margaretha Quena. (2014). Gerakan Pembaruan Hukum Lingkungan Indonesia dan Perwujudan Tata Kelola Lingkungan Yang Baik dalam Negara Demokrasi. Jurnal Hukum Lingkungan Indonesia. Indonesian Center for Environmental Law (ICEL), 01(01): 90

Michael Hopkins. (2003). The Business Case for CSR : Where are we ? International Journal for Business
Performent Management, 5 (23): 125.

Lili Rasjidi dan I. B. Wyasa Putra. (1993). Hukum sebagai Suatu Sistem, Bandung: Remaja Rosdakarya.

Prayekti Murharjanti. (2008). Menutup Akses Menuai Bencana (Potret Pemenuhan Akses Informasi, Partisipasi, dan Keadilan dalam Pengelolaaan Lingkungan Hidup dan Sumber Daya Alam di Indonesia. Mold. I. Jakarta: ICEL.

R. Dwi. (1998). Peranan Akuntansi Sosial dalam Menilai Tanggung Jawab Sosial, Thesis, not published, Malang.

Richard N.Farmer \& Dickerson W. Hogue. (1988). Corporate Social Responsibility. Toronto: DC Healt and Company.

Sonny A . Keraf. (1998). Etika Bisnis : Tuntutan dan Relevansinya. Yogyakarta: Kanisius.

Teguh Sri Pembudi. (2005). CSR Suatu Keharusan, dalam Investasi Sosial, Jakarta: Puspinsos.

Yeremia Pratama Ardi dan Gunawan Widjaja. (2008). Risiko Hukum \& Bisnis Perusahaan Tanpa CSR. Jakarta: Forum Sahabat.

\section{Website :}

Prince of Wales International Business Forum, see, http://www.ibl.or.id [Accessed 8 Mei 2016] 